Chirurgia (2019) 114: 437-442

No. 4 July - August

Copyright@ Celsius

http://dx.doi.org/10.21614/chirurgia.114.4.437

\title{
Relevance of Finite Element in Total Knee Arthroplasty - Literature Review
}

\author{
Roman Popescu1, Emil G.Haritinian ${ }^{1,2}$, Stefan Cristea ${ }^{1,3}$ \\ ${ }^{1}$ Carol Davila University of Medicine and Pharmacy, Bucharest, Romania \\ ${ }^{2}$ Clinical Hospital of Orthopedics and Traumatology and Osteoarticular TB "Foișor", Bucharest, Romania \\ ${ }^{3}$ Department of Orthopaedics and Traumatology, "Sf Pantelimon" Emergency Hospital, Bucharest, Romania
}

Corresponding author:

Popescu Roman, Phd

Carol Davila University of Medicine

and Pharmacy, Rectorate

Dionisie Lupu Street, no.37, 020021

District 1 - Bucharest, Romania

E-mail: popescu_roman@yahoo.com

Abbreviations:

CFR-PEEK - Carbon fiber reinforced

- polyetheretherketone

CoCrMo - Cobalt Chromium

Molybdenum

CR- Cruciate- retaining

CT - Computer Tomograph

FE - Finite element

FEM - Finite element method

PEEK - Polyetheretherketone

SS $316 \mathrm{~L}$ - Stainless steel

Ti6Al4V - Alpha-beta titanium

TKA - Total knee arthroplasty UMWPE - Ultrahigh molecular weight polyethylene

\section{Rezumat}

Importanța elementului finit în artroplastia totală de genunchi - sinteză de literatură

Artroplastia totală de genunchi este un procedeu chirurgical cheie în tratamentul gonartrozei avansate. Deşi artroplastia totală de genunchi are în general rezultate foarte bune clinice, revizia este de cele mai multe ori necesară din cauza alinierii incorecte a componentelor protetice, ceea ce determină uzură precoce a polietilenei, instabilitate şi decimentare aseptică. În prezent, rata reviziei artroplastiei totale de genunchi este de $5 \%$ la zece ani. Metoda elementului finit este o tehnică numerică care permite modelarea unei geometrii complexe şi a unui sistem de sarcini. Această metodă a apărut ca un instrument de necesitate în domeniul ortopediei pentru a simula si a anticipa condițiile care conduc la complicații sau eşec, pentru a prelungi longevitatea componentelor protetice. Aşadar scopul acestei sinteze de literatură este să evidențieze relevanța utilizării metodei elementului finit în artroplastia totală de genunchi. Studiul literaturii de specialitate a demonstrat că utilizarea analizei elementului finit este frecventă în cadrul artroplastiei totale de genunchi. Aceasta a fost folosită pentru a compara materialele inserturilor pentru a obține cel mai eficient insert cu o uzură cât mai redusă. Utilizând simularea unghiurilor, a forțelor şi a presiunii au fost testate diferite situații de aliniere incorectă pentru ca acestea să poată fi integrate în planificarea pre-operatorie şi să se evite un eventual eşec al artroplastiei totale de genunchi. Analiza elementului finit are un mare potențial de perfecționare a rezultatelor alinierii componentelor protetice şi de asemenea este foarte importantă pentru studierea 
biomecanicii genunchiului supus diferitelor sarcini. Metoda elementului finit este folosită pentru a reduce incidența reviziei şi a îmbunătăți satisfacția pacienților după artroplastia totală de genunchi.

Cuvinte cheie: metoda elementului finit, artroplastia totală de genunchi, uzura polietilenei, satisfacție pacient

\begin{abstract}
Total knee arthroplasty (TKA) is a key surgical procedure for the treatment of severe knee osteoarthritis. Although TKA has very good clinical results, revision knee arthroplasty can sometimes be necessary due to prosthetic components malalignment which leads to early polyethylene wear, instability and aseptic loosening. Currently, the revision risk of TKA at ten years is 5\%. The finite element method (FEM) is a numerical technique which allows the modelling of complex geometry and system of loads. This method is a necessity in the field of orthopedics to simulate or predict the conditions that could lead to complications or failure and react to increase the longevity of TKA. The aim of this literature review is to highlight the relevance of using FEM along with TKA. Specialty literature research shows that the use of finite element analysis is widely spread in total knee arthroplasty. It is used to compare insert materials in order to obtain the most effective method and thus decrease the wear rate. Using simulated angles, forces and stress, FEM tests different malalignment conditions in order to apply these results in the pre-operative planning and avoid a possible TKA failure. The finite element analysis has a great potential of further refining TKA alignment outcome and is very important for the analysis of knee biomechanics under different loads. FEM is used to reduce the incidence of TKA revision and to improve patients' satisfaction after TKA.
\end{abstract}

Key words: finite element method, total knee arthroplasty, polyethylene wear, patient's satisfaction

\section{Introduction}

The main objectives of total knee arthroplasty (TKA) involve relieving knee pain, restoring alignment between the femur and the tibia, achieving knee stability and maintaining articular mobility. Although TKA has very good clinical results, revision knee arthroplasty is often necessary because of prosthetic components malalignment which leads to early polyethylene wear, instability and aseptic loosening. Currently, the revision risk of TKA at ten years is $5 \%(1)$.

The finite element method (FEM) is a numerical technique which allows modelling of complex geometry and system of loads (forces, movement, pressure, acceleration), which provide different analyses in various fields such as static, nonlinear and heat transfer analysis. It also presents the modelling of materials whether they are homogeneous or non-homogeneous, isotropic or anisotropic. In creating the model analysis, there are two stages: the pre-processing and post-processing stage. The first stage describes the model geometry when modelling with finite elements. This means choosing the finite elements, determining the properties of the material and identifying stress conditions. The second stage consists of simulating various stress conditions for the modelled material and concluding with the parametric study (2).

FEM is a necessity in the field of orthopedics in order to simulate or predict the conditions that lead to the aforementioned factors and thus increase the longevity of the prosthetic components.

Recording bone properties from computer 
tomograph (CT) scans using different pieces of software (ANSYS, ABAQUS, CATIA, COSMOS) is frequently practiced to generate a finite element model. It was previously suggested to incorporate the anisotropy and the heterogeneity of the bone in FEM because these influence the stress results (3). Moreover, a failure to account for anisotropy can result in a faulty prediction of bone stress (4). A real prosthesis is scanned with a microlaser, then integrated into the software and a model is created through 3D elements. In the software the geometry, bone properties and the loading conditions are modelled (2).

The purpose of this literature review is to highlight the relevance of FEM in TKA.

\section{Material and Methods}

A literature review was performed using the following keywords: "malalignment of the tibial component in TKA", ,polyethylene wear and finite element" and "finite element in TKA". The following database were consulted: PubMed (https://www.ncbi.nlm.nih.gov/pubmed I), Google Scholar (https://scholar.google.ro/) and Springer (https://www.springer.com/gp).

Initially, we retrieved 35 articles, from which 10 were duplicates. We then evaluated 25 potentially relevant articles. The final selection contained only 11 articles (Table 1 sumarizes all the general data of the included articles). We excluded 14 articles due to insufficient details about FEM in TKA. Otherwise, the articles were outdated.

\section{Results}

Latypova et al. (4) compare isotropic and

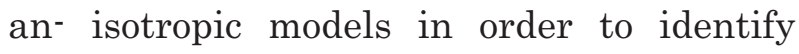
strains in resurfaced and non - resurfaced patella and to demonstrate that the isotropic model better predicts strains than the anisotropic one in both types of patella. Zhang et al. (5) note that a prediction for a faster polyetyhlene wear can be made separately on the medial and lateral compartments.

Kang et al. (6) observe, based on calculations and comparisons of ligament forces, that the internal rotation of the femoral component and the alignment in valgus of the tibial component can affect the medial collateral ligament, while the external rotation of the femoral component and varus alignment of the tibial component increase the lateral collateral and popliteofibular ligament and

Table 1. Overview of the included articles

\begin{tabular}{|c|c|c|c|c|}
\hline Author & $\begin{array}{c}\text { Year of } \\
\text { publication }\end{array}$ & Journal & Software used & Finite element analysis of \\
\hline Latypova et al. (4) & 2017 & Medical Engineering and Physics & SOLIDWORKS & Prediction of patellar strain \\
\hline Zhang et al. (5) & 2017 & Journal Engineering in Medicine & ABAQUS & Contact mechanics and wear prediction \\
\hline Kang et al. (6) & 2018 & $\begin{array}{l}\text { Journal of the American Academy } \\
\text { of Orthopaedic Surgeons }\end{array}$ & ABAQUS & Prediction of malpositioning \\
\hline Alotta et al. (7) & 2018 & Journal of Strain Analysis & ABAQUS & Wear prediction \\
\hline Mou et al. (8) & 2018 & $\begin{array}{l}\text { Journal of Orthopaedic Surgery } \\
\text { and Research }\end{array}$ & HYPERMESH & $\begin{array}{l}\text { Optimization of parameters for femoral } \\
\text { component implantation }\end{array}$ \\
\hline Madeti et al. (9) & 2018 & $\begin{array}{l}\text { International Journal of Experimental } \\
\text { and Computational Biomechanics }\end{array}$ & ANSYS & Suitable materials for knee implants \\
\hline Mestar et al. (10) & 2018 & $\begin{array}{l}\text { Journal of Biomimetics, Biomaterials } \\
\text { and Biomedical Engineering }\end{array}$ & ANSYS & Mechanical behaviour of knee prosthesis \\
\hline Azam et al. (11) & 2018 & MATEC Web of Conferences & SOLIDWORKS & Contact stress in TKA \\
\hline Kang et al. (12) & 2017 & Composite Structures & MIMICS & Tibial inserts \\
\hline Moewis et al. (13) & 2018 & PLOS ONE & ABAQUS & $\begin{array}{l}\text { Evaluating physiological joint line TKA } \\
\text { designs }\end{array}$ \\
\hline Koh et al. (14) & 2019 & Lubricants & ABAQUS & Wear prediction \\
\hline
\end{tabular}


anterior lateral structure forces.

Alotta et al. (7) make predictions by comparing the elastoplastic and viscoelastic models, based on the calculation of the wear factor.

Mou et al. (8) determine that minor changes in the prosthesis positioning parameters may have a great influence in the stress generated in the prosthetic components.

Madeti el al. (9) apply FEM on the assembled and dismantled knee components and test the pressure at different values in order to compare endurance and longevity.

Mestar et al. (10) create different models of knee components ( types of alloy - Ti6Al4V, Co-CR-Mo, SS 316 L, oxidized zirconium, model with cement) and also model a normal knee, which are tested for various values of loads and stress and then are compared.

Azam et al. (11) propose the use of three angle flexions with various loads so that they can be applied on a personalized prosthesis design as opposed to the current designs of TKA components.

Kang et al. (12) demonstrate that by shifting the materials in the tibial insert it creates different biomechanical effects on the ligaments and muscles in two surgical techniques - posterior stabilized (PS) and cruciateretaining (CR) TKA.

Moewis et al. (13) conclude that a $5-10^{\circ}$ malrotation (either internal or external) of the knee components leads to a greater pressure on the medial compartment.

Koh et al. (14) compare three types of insert material: ultrahigh-molecular weight polyethylene (UMWPE), polyetheretherketone (PEEK) and carbon fiber- reinforced polyetheretherketone (CFR-PEEK) using various parameters (rate, volumetric wear, wear depth) to calculate the best endurance.

\section{Discussion}

Koh et al. (14) demonstrate that using FEM to predict polyethylene wear is a convenient and less expensive method than in vitro wear-testing machines. In their study, three types of inserts were tested: ultrahigh- molecular weight polyethylene (UMWPE), polyetheretherketone (PEEK) and carbon fiber- reinforced polyetheretherketone (CFRPEEK) to predict which has the best endurance. Essentially,by using the laws of physics (Young's Modulus, Poisson's ratio), through a special software, different conditions of stress were simulated in order to help the surgeon choose the optimal insert for implanting. They conclude that CFR- PEEK is a good alternative to UMPWE insert, because the CFR-PEEK insert resisted to a higher contact pressure and had a smaller contact area, which lead to a slower rate of wear and less stress on the tibial component. Kang et al. (12) in a separate finite element (FE) study use the same three implants in two techniques, posterior-stabilized (PS) and cruciateretaining (CR) TKAs, in order to assess the biomechanical effect on the knee components. It is primarily highlighted in their study that changing the insert material determines different biomechanical effects on ligaments and muscles depending on which technique is used. For instance, the force of the quadriceps in flexion was reduced by using CFR-PEEK and PEEK as opposed to UMWPE in both techniques, but only in CR-TKA was the pressure on the collateral ligament reduced by CFR-PEEK and PEEK.

Incorrect positioning of the TKA prosthesis may determine the loss of the neutral mechanical axis in the lower extremity. This can happen when the surgeon cuts the tibia incorrectly either laterally or medially and consequently results in malalignment. Therefore, in order to prevent malalignment, FEM analyses the knee biomechanics, applying different angles of rotation useful to the surgeons in the preoperative planning of TKA. Most studies test the rotation of the tibial component because of the tibia's geometric complexity and because the anatomical landmarks used to position the tibial component are not precise enough to always avoid postoperative malalignment. Tibial alignment is very important in TKA because a varus or valgus malalignment will determine a faster polyethylene wear and respective joint instability. Also, it is shown that in neutral 
alignment a larger contact area on the polyethylene (PE) insert means a smaller stress on the tibial component (15).

Moewis et al. (13) conclude that rotational malalignment is determined by the influence of the prosthesis design with physiological joint line on the stress distribution on the polyethylene.

Mestar et al. (10) propose a different approach for the orthopaedic surgeons in order to determine an optimal surgical model. It tests physiological forces and stress on both a normal knee and the models of knee prosthesis to show that by using materials such as elastomer and cement, the stress decreases, because those materials absorb more stress.

Allota et al. (7) compare an ultrahighmolecular weight polyethylene component made out of viscoelastic material with one made out of elastoplastic, establishing that the one made out of viscoelastic material is better suited for an accurate estimation of the polyethylene wear using FEM. It is noted that elastoplastic material models undervalue stress due to the stress-easing effect of plasticity. Therefore it is suggested that the experimental data obtained for the viscoelastic material model should be used in making new TKA implants.

Mou et al. (8) apply FEM to show that for a correct alignment in TKA, the use of valgus and external rotational angles are very important for the femoral component and propose this technique to be used for the tibial component positioning.

Kang et al. (6) by the use of FEM, link the stress on medial PE insert with internal rotation and malalignment in varus and the stress on the lateral PE insert with external rotation and malalignment in valgus.

Zhang et al. (5) prove that computer simulating stress separately on the medial and lateral compartment is preferable to using total axial load for predicting contact biomechanics and polyethylene wear.

Furthermore, in some studies, the use of FEM led to the conclusion that polyethylene tibial implant applies more pressure on the cancellous bone than the metal equivalent and also that, with the metal tray, more cancellous bone is lost in the proximal tibia because of resorption (16). Although polyethylene has lower strength compared to metal, the strength it has is enough for the survival of the implant (9).

Lastly, FEM demonstrates that the stresses simulated in the proximal tibia extremity in TKA are more susceptible to the medial tilt of the tibial component in the frontal plane than to the lateral tilt (17).

\section{Conclusion}

FEM has proven to be efficient in simulating various situations and complications in TKA in order to improve the results.

The finite element analysis demonstrates great potential for further refining TKA alignment outcome while also proving very important in the analysis of knee biomechanics under different loading and providing surgeons with the the ability to obtain an accurate alignment of the tibial component.

FEM is a good method to reduce the incidence of TKA revision and to improve patients' satisfaction after TKA.

\section{Conflict of Interests}

The authors declare no conflict of interest.

\section{Funding}

No funding was required for this study.

\section{Ethical Approval}

Ethical approval was not required for this study.

\section{Informed Consent and Patient Details}

Informed consent was not applicable to this study.

\section{References}

1. Khan M, Osman K, Green G, Haddad FS. The epidemiology of failure in total knee arthroplasty. The Bone and Joint Journal. 2016; 98-B (1 Suppl A): 105-12.

2. Sahu NK, Kaviti AK. A review of use FEM techniques in Modeling of 
Human Knee Joint. Journal of Biomimetics, Biomaterials and Biomechanical Engineering. 2016;28:14-25.

3. Au AG, Liggins AB, Raso VJ, Amirfazli A. A parametric analysis of fixation post shape in tibial knee prostheses. Med Eng Phys. 2005; 27(2):123-34.

4. Latypova A, Pioletti DP, Terrier A. Importance of trabecular anisotropy in finite element predictions of patellar strain after Total Knee Arthroplasty. Med Eng Phys. 2017;39:102-105.

5. Zhang J, Chen Z, Wang L, Li D, Jin Z. Load application for the contact mechanics analysis and wear prediction of total knee replacement. Proc Inst Mech Eng H. 2017;23(15):444-454.

6 Kang K-T, Son J, Kwon SK, Kwon O-R, Park J-H, Koh Y-G. Finite element analysis for the biomechanical effect of tibial insert materials in total knee arthroplasty. Composite Structures 2018; 201:141-150.

7. Alotta G, Barrera 0, Pegg EC. Viscoelastic material models for more accurate polyethylene wear estimation, Journal of Strain Analysis 2018; https://doi.org/10.1177/0309324718765512.

8. Mou Z, Dong W, Zhang Z, Wang A, Hu G, Wang B, et al. Optimization of parameters for femoral component implantantion during TKA using finite element analysis and orthogonal array testing. J Orthop Surg Res. 2018;13(1):179.

9. Madeti BK, Rao CS. Finite analysis for knee implants with suitable material combinations. International Journal of Experimental and Computational Biomechanics. 2018;4(2-3):113-124.

10. Mestar A, Zahaf S, Zina N, Boutaous A. Development and validation of a numerical model for the mechanical behavior of knee prosthesis analyzed by the finite element method. Journal of Biomimetics,
Biomaterials and Biomedical Engineering. 2018;37:12-42.

11. Azam NMA, Daud R, Ayu M, Ramli J, Hassan MFB, Shah A, et al. The effect of knee flexion angle on contact stress of total knee arthroplasty. MATEC Web of Conferences. 2018; 225. 03009; https://doi.org/10.1051/matecconf/201822503009.

12. Kang K-T, Son J, Kwon O-R, Koh Y-G. Malpositioning of prosthesis: patient-specific total knee arthroplasty versus standard off-the-shelf total knee arthroplasty. J Am Acad Orthop Surg Glob res Rev. 2017;1(4):e020.

13. Moewis P, Checa S, Kutzner I, Hommel H, Duda GN. Physiological joint line total knee arthroplasty designs are especially sensitive to rotational placement - A finite element analysis. PLOS ONE 2018;13(2): e0192225.

14. Koh Y- G, Lee J-A, Kang K-T. Prediction of wear on tibial inserts made of UHMPWE, PEEK, and CFR-PEEK in total knee arthroplasty using finite-element analysis. Lubricants. 2019; 7(4):30.

15. Suh D-S, Kang K-T, Son J, Kwon O-R, Baek C, Koh Y-G. Computational study on the effect of malalignment of the tibial component on the biomechanics of total knee arthroplasty. Bone Joint Res. 2017;6(11):623-630.

16. Thompson SM, Yohuno D, Bradely WN, Crocombe AD. Finite element analysis: a comparison of an all- polyethylene tibial implant and its metal-backed equivalent, Knee Surg Sports Traumatol Artrhosc. 2016;24(8):2560-6.

17. Daniel de Castilho Paulo. Influence in load distribution of the alignment of the tibial component in total knee prosthesis; https://fenix.tecnico.ulisboa.pt/downloadFile/395142133138/Artig 0\%20Daniel\%20de\%20Castilho\%2055534.pdf. 